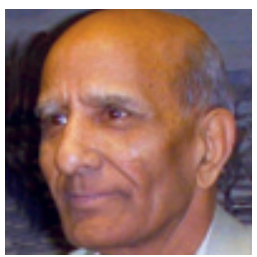

\title{
Julehilsen med kondolansekort
}

\section{Året var 1971. Med store forventninger satt jeg på bussen til Oslo. Sammen med en annen mann fra Pakistan hadde jeg bestemt meg for å oppleve den store norske julefesten på byen.}

Det led mot kveld. Vi vandret oppover Karl Johan med overveldende lysdekorasjoner og grantrepynt. Mens vi gikk der, ble det færre og færre mennesker. De simpelthen forsvant. Det kom heller ikke flere ut av de blå trikkene som ellers gikk så flittig i hovedgaten. Jernskinnene lå bare som kalde minner. Da vi passerte Universitetsplassen på vei mot kongens slott, var den ellers så livlige byen gått $i$ dvale. Vi to fra Pakistan ble etter hvert de eneste som feiret jul i gatene i hovedstaden. Fest hjemme i Pakistan var ensbetydende med et sydende folkeliv, trommer og musikk på gatene, gjøglere og sjonglører. Men Oslo var i unntakstilstand under den store festen.

Vi frøs og hastet tilbake til bussholdeplassen på Ankertorget for å komme oss hjem. Men her var ingen buss, bare en enslig fyllik. Han ønsket oss god jul og sa at vi var kamerater og at han var glad i oss. Han viftet med sin halvfulle flaske, åpenbart lykkelig over at to levende sjeler hadde dukket opp og forsikret igjen og igjen at «We are friends, I love you! Happy Christmas!».

Vi gikk fra Ankertorget til Kirkeveien denne første julekvelden i Norge. Her var bokstavelig talt haugevis av mine pakistanske landsmenn stablet sammen uten noen viten om den norske julefesten.

Utover høsten hadde jeg følt at min tilværelse var trygg og stabil, med jobb og hybel på gården utenfor Oslo. Da adventstiden tok til, dreide det seg om julen, og jeg trakk til meg alt jeg kunne av kunnskap om høytiden. Jeg hadde oppfattet at man sendte kort til hverandre, akkurat som vi gjorde i Pakistan ved høytidene. Julekort. Så jeg besøkte en landhandel i Skedsmo. Med stor kjærlighet til mine arbeidskolleger og venner plukket jeg ut de vakreste og dyreste kortene jeg fant. De var dekorert med naturtro blomster. I rimelig god tid før jul postla jeg et kort til hver av mine nye venner i Norge.

Første arbeidsdag i romjulen gikk Roger frem og tilbake med lange skritt på det iskalde fabrikkgulvet og ropte: - Mye snø i julen - kaldt.

Maskinene sto stille. - Vi holder det ikke ut lenger. Kulden er på sitt verste. Vi må ta en varmepause, sa Henrik. Jeg gikk til blandemaskinen. Andre sto rundt varmeblåseren. Roger gestikulerte med tydelige bevegelser. Bevegelsene stoppet. Så ble det stille igjen. Mange sto i ring rundt Roger. De så på et papir som Roger holdt $i$ hånden. Noen ganger brøt de ut i høy latter. De kom langsomt mot blandemaskinen og stoppet ved siden av meg. Så på hverandre som om de ville prate med meg, uten å ha bestemt hvem som skulle begynne.

- Du skulle ha startet varmemaskinen i natt, noe du ikke gjorde. Vi må gå i spiserommet og vente minst et par timer før vi kan starte arbeidet, sa Henrik, uten å se på meg.

- Jeg glemte det, beklager.

- Vi går inn i spiserommet og snakker videre, sa Roger.

De satte seg ned i spiserommet på sine faste plasser med hver sin skitne kaffekopp foran seg. De pratet og lo.
- Feirer dere jul i Pakistan? spurte Nicolay.

- Ja, det gjør vi.

Jeg så ut gjennom vinduet på den uendelige lyseblå himmelen, full av grå og flytende skyer. Skisporene foran vinduet ble smalere og smalere oppover skråningen og forsvant brått ved overgangen til skogen. Telefonen ringte. Roger tok den. Han snakket og lo. Innimellom nevnte han mitt navn, uten at jeg kunne oppfatte sammenhengen i samtalen. De lo høyt og uhemmet.

- Sender dere julehilsener til venner og bekjente i Pakistan? ville Henrik vite.

- Ja.

- Hva skriver dere, da?

- Vi skriver forskjellige ting, svarte jeg likegyldig.

Alle lo.

- Sender dere kondolansebrev til venner og bekjente som julehilsen? Han så meg dypt i øynene med et hjertelig, varmt smil.

- Kondolansebrev, hva er det for noe?

Roger brettet ut et kort og viste meg julekortet jeg hadde sendt ham. - Se her! Du sendte dette kondolansekortet til meg. Du har sendt et lite, vakkert kondolansekort med blomsterdekorasjoner til hver av oss!

- Jeg vet ikke forskjell på disse kortene. Jeg sendte det vakreste kortet med masse blomsterdekorasjoner på som jeg fant akkurat som vi gjør i Pakistan, sa jeg lettet og glad.

Og Roger leste den lille teksten: - «Min dypeste medfølelse i denne tunge tida ...»

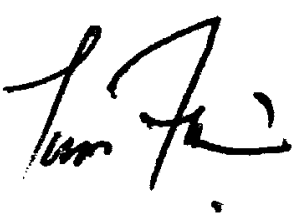

\section{I neste nummer:}

\author{
Brannskader hos barn \\ Lokalbehandling av akne \\ Pasientplikter
}

Diabetisk retinopati

Hepatitt C

Akuttmedisinske team 